\title{
Nonmarket social and political strategies - New integrative approaches and interdisciplinary borrowings
}

\author{
Jedrzej George Frynas \\ Roehampton Business School, University of Roehampton, London, UK
}

John Child

Birmingham Business School, University of Birmingham, UK

Shlomo Y. Tarba

Birmingham Business School, University of Birmingham, UK

PUBLISHED IN: BRITISH JOURNAL OF MANAGEMENT, VOL. 52, NO.4, 2017

DOI: $10.1111 / 1467-8551.12253$

\begin{abstract}
This paper introduces a special issue of the British Journal of Management on social and political strategies in the non-market environment. On the one hand, it reviews the extant research on the possible forms of interaction between Corporate Social Responsibility (CSR) strategies and Corporate Political Activity (CPA): CSR-CPA complementarity, CSR-CPA substitution and mutual exclusion between CPA and CSR. On the other hand, the paper provides an overview of the recent contributions of non-business disciplines - psychology, sociology, economics, politics and history - to nonmarket scholarship and, above all, the potential future scholarly contributions of these disciplines.
\end{abstract}

This special issue addresses business strategies in the nonmarket environment. By their very definition, strategies in the nonmarket environment stand in contrast to those in the market environment. Following Baron's (1995:47-48) definition, "the nonmarket environment consists of the social, political, and legal arrangements that structure the firm's interactions outside of, and in conjunction with, markets", whereas "the market environment includes those interactions between the firm and other parties that are intermediated by markets or private agreements". In other words, nonmarket strategies are about managing the wider institutional context within which companies operate, as opposed to the more narrowly economic context of market competition.

The academic dichotomy between market and nonmarket environments is not unproblematic. Our understanding of markets and of nonmarket institutions is socially constructed, and any market transaction is arguably an outcome of the social, political, cultural, and economic forces 
that are shaping it (e.g., Astley, 1985; Abolafia, 1998; Fligstein, 1996). Some business scholars convincingly assert that, ultimately and for their benefit, companies should analyse and manage their external - market and nonmarket - environments in an integrated fashion (e.g., Baron, 1995; Holburn \& Vanden Bergh, 2014), just as scholars of sustainable development and the social responsibilities of business suggest that companies and financial markets should integrate environmental, social, and governance concerns into their day-to-day strategic decision-making for the benefit of the wider society (e.g., Elkington, 1994; Busch et al., 2016).

While such integrated strategies may be the ultimate goal, the study of nonmarket strategies is valuable and necessary. Business managers face a vast array of nonmarket risks and opportunities in an increasingly complicated and multi-polar world (the emergence of a relatively large number of new power centres globally), as demonstrated by various business executive surveys and consultancy reports (e.g., PricewaterhouseCoopers, 2016; World Economic Forum, 2016). In such a world, a multinational enterprise (MNE) may face an increasingly integrated international economy on the one hand, and a fragmented nonmarket environment on the other (Kobrin, 2015). For example, a large MNE may decide to engage in a merger with another company to benefit from global market opportunities, but the merger deal may need to be approved by a dozen different regulatory authorities around the world. Likewise, a multinational petroleum company may have a global production system but successful production activities are dependent on different nonmarket actors in the different countries where the firm operates, such as different national government agencies, domestic pressure groups, and so on.

Navigating this nonmarket environment often requires skill sets that are very different from the more conventional commercial ones, both in terms of the required political skills and capabilities (e.g. Frynas, Mellahi \& Pigman, 2006; Oliver \& Holzinger, 2008), and social skills and capabilities (e.g. Hart, 1995; Russo \& Fouts, 1997); consequently, the study of nonmarket environments may require different research approaches and methods.

\section{Rationale for this special issue}

Scholarly interest in nonmarket strategies has existed for several decades (for recent reviews, see Mellahi et al., 2016; Boddewyn, 2016). We now have considerable knowledge of the antecedents (e.g., Hillman et al., 2004), the organizational performance outcomes (e.g., Rajwani \& Liedong, 2015), and the contextual diversity (e.g. Örtenblad, 2016) of nonmarket strategies. Other recent studies have explored inter alia investor reactions to nonmarket strategies (Arya \& Zhang, 2009; Werner, 2017), the socially constructed nature of nonmarket strategies (Orlitzky, 2011; Gond, Cabantous \& Krikorian, 2017) and wondered to what extent collective political actions and private political actions are substitutes or complements (Jia, 2014).

However, research on nonmarket strategies has suffered from two crucial limitations. On the one hand, the relevant scholarship has been highly fragmented for a long time and has largely disintegrated into separate political and social domains. Two parallel strands of nonmarket strategy research have emerged in isolation: one that examines corporate social responsibility (for a review of the CSR literature, see Aguinis \& Glavas, 2012) and the other that examines corporate political activity (for a review of the CPA literature, see Lawton et al., 2013a). Scholars have long articulated the need for an integration of these two lines of research (Baron, 2001; McWilliams et al., 2002; Rodriguez et al., 2006), but it was only relatively recently that they have started to explore this integration (see Frynas \& Stephens, 2015; Mellahi et al., 2016). 
The lack of integration of the political and social/environmental domains of nonmarket strategy research manifests itself inter alia in the failure to understand the substitution effects between company political and social strategies or the failure to understand the social impact of corporate political strategies on other stakeholder groups outside the organization.

On the other hand, research on nonmarket strategies has suffered from the failure to integrate insights and methodologies from disciplines outside business studies such as political science, legal studies, sociology, and history. While some influential theoretical lenses used in CSR and CPA scholarship originated from related disciplines outside business and managementincluding resource-dependence theory, institutional theory, and social movement theorynonmarket scholarship largely imitated the application of these theories to other branches of business and management research, rather than developing them for its own purposes (cf. Suddaby et al., 2011; Whetten et al., 2009). Additionally, in those instances in which borrowing did take place in nonmarket scholarship, its quality was sometimes poor, as notably evidenced by the superficial application of Habermasian theories to recent Political CSR scholarship (see the critique by Whelan, 2012). Given that, by definition, nonmarket research touches on the political, legal, and social aspects of company strategies, one would expect and welcome a much greater cross-fertilization with non-business disciplines in order to address those aspects of nonmarket strategy that are currently insufficiently explained by the existing approaches.

Underlying the rationale of this special issue has been our desire to help, in a modest way, fill these two research gaps. Consequently, we sought papers that either offer new pathways for the integration of the political and social research domains in nonmarket research, and/or offer new pathways for the enrichment of our understanding of nonmarket strategies with insights and theories from outside business studies. The four papers in this special issue help to address these research gaps in very different ways.

\section{Integration of social and political perspectives}

In recent years, CSR scholarship has started to address the political aspects of CSR (for a review, see Frynas \& Stephens, 2015), although many studies approached political CSR from a narrow normative research agenda, advocating a new conception of Political CSR that ascribes new roles to business in the delivery of public goods, which postulates normative theory to the exclusion of descriptive theory and addresses changes in global governance to the exclusion of the traditional domestic political process (e.g., Scherer \& Palazzo, 2007; Scherer et al., 2016). CPA scholarship also explored some social aspects of political activities-e.g., CPAs related to environmental regulation, such as regulation related to climate change (e.g., Kolk \& Pinkse, 2007; Levy \& Egan, 2003) — or the role of social mobilization in CPAs (e.g., Walker, 2012; McDonnell \& Werner, 2016), but, until recently, it has largely failed to specifically explore the CSR-CPA relationship. In effect, only relatively few empirical studies have started to explore the nature of the interactions between CSR strategies and CPAs (as discussed below), and their results to-date appear highly contradictory.

\section{CPA-CSR complementarity}

There has been an explicit assumption among various scholars that CSR and CPA are complementary and may need to be aligned (e.g., den Hond et al., 2014; Liedong et al., 2015). Indeed, recent empirical research suggested that CSR weakens the potentially negative impact of CPA (Liedong et al., 2015; Sun, Mellahi \& Wright, 2012), that CSR helps to gain and to 
maintain political access (Wang \& Qian, 2011; Gao \& Hafsi, 2017) and, alternatively, that CPA offsets negative CSR records (Alakent \& Ozer, 2014). The important conceptual papers by den Hond et al. (2014) and Rehbein \& Schuler (2015) outlined the various possible ways in which CSR can strengthen CPA, and vice versa.

CPA can strengthen CSR activities through several mechanisms. Interactions with political actors can assist organizations in selecting CSR priorities by identifying significant social and political issues. CPA can provide critical information, support, or favourable regulation to enhance the economic viability of CSR activities. CPA may also help to increase the credibility and legitimacy of CSR activities (den Hond et al., 2014).

Conversely, CSR can strengthen CPA by facilitating access to the political system and its efficacy. CSR can improve human capital resources (e.g., issue expertise), organizational capital resources (e.g., legitimacy) and geographic presence in a political constituency. CSR, as a CPA strategy, may also lessen the necessity for financial donations to politicians or may reduce the cost of demonstrating compliance to regulation (den Hond et al., 2014; Rehbein \& Schuler, 2015).

\section{CPA-CSR substitution}

In contrast, the paper by Liedong, Mellahi \& Rajwani (2017) in this special issue finds no evidence for complementarity. The authors found that CSR helps to lower perceptions of risk exposure but is ineffective when combined with managerial political ties (MPTs), thereby 'suggesting the existence of a form of "cannibalization" whereby MPTs erode the gains of CSR'. This gives some credence to the idea that CSR and CPA may mutually act as substitutes. Other empirical research provided some evidence that, for example, companies may donate less to charitable causes because they have good political connections (Zhang, Marquis \& Qiao, 2016). In this case, CPA substitutes for CSR. Another recent study found that those Chinese companies that increase CSR in the aftermath of changes of city-level mayors can build political networks and can be rewarded with government subsidies (Lin et al., 2015). In this case, CSR substitutes for CPA.

In general terms, companies may have a preference for CSR as a substitute for CPA because the latter is vulnerable to the loss of political ties due to the departure of managers with personal ties to political decision-makers (Sun et al., 2012), or because potential political and regulatory shocks and evolutionary changes may undermine the value of a company's existing political ties (Siegel, 2007; Sun, Mellahi \& Thun, 2010). Most notably, the politicians or political factions in power may be displaced, thus exposing those companies that had cultivated close relations with them (Darendeli \& Hill, 2016).

By contrast, CSR tends to be more politically neutral and its organizational value is more likely to outlast changes in government or managerial departures. In addition, companies with a reputation for CSR activities may also be reluctant to become involved in political activities (including even government-sponsored sustainability initiatives) because of the perceived risk of later accusations of 'greenwashing' and hypocrisy (Kim \& Lyon, 2011).

\section{CPA-CSR incompatibility}

Some research also provided evidence that CSR and CPA may be mutually exclusive. For example, some research on philanthropy (which can be viewed as a sub-set of CSR) suggests 
that philanthropy may not necessarily be undertaken for rational, instrumental reasons, because it is an outcome of employee empathy (e.g. Grant, Dutton \& Rosso, 2008) or because it consists of adhoc corporate disaster relief following some catastrophic events (e.g. Crampton \& Patten, 2008), hence philanthropy may not be a substitute for CPA or complementary with CPA under those circumstances. Boddewyn and Buckley (2017) in this special issue and other studies (Wang \& Qian, 2011; Gao \& Hafsi, 2017) suggest that philanthropy may still lend itself as a substitute for CPA or complementary with CPA, but some societal issues such as conflict mitigation and resolution may just be fundamentally unsuited to becoming part of a company's CPA agenda.

As a notable example, Jamali \& Mirshak (2010) investigated the extent to which MNEs can help in conflict mitigation and resolution, and peace building efforts in conflict-prone host countries. While the authors actually provided a normative argument in favour of such roles for companies in conflict-prone regions, their actual empirical evidence pointed to the incompatibility of goals and means between the social activities of MNEs and the political activities necessary to help in conflict mitigation and resolution, and peace building. The surveyed companies had a fundamentally neutral and apolitical stance, had perceptions of low power vis-a-vis the conflict sides and failed to appreciate the collective interest in providing solutions to conflicts. At the same time, the companies believed that the means and expertise at their disposal were not necessarily appropriate in conflict situations. This research suggests that - at least in some areas of societal engagement - the integration between CSR and CPA may be extremely difficult.

At the same time, within some companies, CSR and CPA may be seen as separate mutually exclusive activities because of the existing internal organizational structures and corporate values. These underpin the development of nonmarket activities by companies, stemming from, inter alia, the structuring of business groups (Dieleman \& Boddewyn, 2012), ownership structures (Lawton et al., 2013b), the internal organization of the external affairs function (Doh et al., 2014), and the nature of the internal relationships between public affairs managers and colleagues in other subsidiaries (Barron, Pereda \& Stacey, 2017). For example, the external affairs function at the German airline Lufthansa specifically benefitted from the complementarities of integrating social and political activities, while the creation of a similar European external affairs function at Tata Consultancy Services (an affiliate of India's Tata Group) had few consequences for political activities because its remit was strictly limited to social and environmental activities (Doh et al., 2014). Thus, we still need to learn considerably more about the effects of organizational structures and corporate values on CSR-CPA integration.

\section{The way forward}

Based on the above discussion, we conclude that integration, substitution, and mutual exclusion are all possible forms of interaction between corporate social activities and corporate political activities. Our model in Figure 1 visualizes these possible forms of interaction.

- Figure 1 about here -

We should recognize, of course, that different types of CSR or CPA may elicit different interactions, for example, a company's high expenditure on environmental protection measures may make it redundant for it to lobby the government for lower environmental regulatory standards (substitution effect), whereas a company's expenditure on charitable projects that are 
valued by politicians may help to improve corporate political ties (complementarity effect). Similarly, it is possible that complementarity effects may be more likely in some institutional contexts; for example, countries in which the government intervenes more frequently in the economy, such as China, and less likely in a country with relatively few government interventions, such as Switzerland (on China, see Wang \& Qian, 2011; on Switzerland, see Helmig, Spraul, \& Ingenhoff, 2016).

Given that there can be much variance in CSR-CPA interactions, future research should investigate how the nature of these interactions may differ between different types of CSR and CPA, different institutional environments, different industry contexts, different types of organizations, internal organizational arrangements or individual business leaders, or how these interactions change over time.

At this stage, one can pose the fundamental question as to the extent to which we can neatly divide all corporate nonmarket activities into CSR and CPA, given that the political and social aspects of nonmarket interventions are so often intertwined. Some key characteristics enable us to distinguish CSR from CPA. Notably, CSR tends to be an open, often well publicized activity that can be imitated by others (McWilliams \& Siegel, 2011; Frynas, 2015), whereas CPA tends to be conducted behind closed doors (Boddewyn \& Brewer, 1994), which is more a difference of process rather than of intent. But nonmarket activities may be simultaneously aimed at both the political constituency and the wider society. If CSR is solely motivated by helping a company influence a government (as in the example of the casinos in the Boddewyn $\&$ Buckley paper in this special issue) or if political engagement is motivated by social and ethical concerns (as in the case of the creation of social and environmental private regulation to fill in for its inadequate state counterpart), should we treat such activity as CSR or CPA?

In addition, companies are increasingly getting involved in emotive and publicly contested socio-political issues that do not neatly fall into either the traditional CSR or the CPA categories; for example, Volkswagen's support for the influx of refugees in Germany, Lush Cosmetics' support for LGBT education in the United States, or Ctrip's opposition to the government's 'one-child policy' in China (Nalick et al., 2016). Therefore, the 'nonmarket' label may ultimately be more helpful than CSR and CPA, but our concern here is with integrating CSR and CPA in scholarship and in practice in view of the fact that the two types of activities still tend to be viewed as distinct and are addressed in distinct fields of study.

\section{Non-business insights on nonmarket strategies}

Nonmarket strategies are about addressing those environmental forces that are the outcome of political, social, or historical processes. However, scholarship on nonmarket strategies has been slow at integrating insights and methodologies from political science, sociology, history and other related disciplines. In recent years, there has been a rising interest in nonmarket research among psychologists (e.g., Rupp \& Mallory, 2015; Gully et al., 2013) and - to a lesser extentsociologists (e.g., Lim \& Tsutsui, 2012; Walker \& Rea, 2014), but there has been little interest from, say, historians or political scientists.

Mellahi et al. (2016:167) noted that "borrowing new insights from non-business disciplines may potentially lead to some of the greatest advances in our understanding of nonmarket strategy". The full promise of insights from non-business disciplines for nonmarket scholarship still remains unfulfilled. Therefore, it may be useful to scope out how nonmarket scholarship 
could benefit from such insights. Here, we provide a brief overview of the recent contributions of non-business disciplines to nonmarket scholarship and, above all, their potential future contributions. Table 1 summarizes some of the promising theoretical approaches and the related future research questions.

- Table 1 about here -

\section{Psychology and nonmarket research}

According to a survey of organizational psychologists conducted by the Society of Industrial and Organizational Psychology a few years ago, CSR was one of the top trends affecting the workplace (reported in Glavas, 2016). In fact, various studies of employment relations borrowed psychological theories to explore aspects of those workplace relations that are closely related to CSR (see discussion below). At the same time, business and management scholars have been making calls for more nonmarket research at the individual level of analysis, an endeavour in which psychological theories could play a leading role (e.g., Aguinis \& Glavas, 2012; Morgeson et al., 2013; Hillenbrand et al., 2013).

Psychological research and theories already have an established presence in those micro-level studies of employment relations that have natural linkages to CSR concerns - such as worklife balance and employee voice research - and have started affecting CSR scholarship in general (Rupp \& Mallory, 2015; Glavas, 2016). Examples of psychological theories that can be useful in explaining nonmarket factors at the individual level include, for example, cognitive categorization theory (cf. Lord \& Maher 1991), organizational justice theory (cf. Greenberg, 1987) psychological contract theory (cf. Robinson, Kraatz \& Rousseau, 1994), and image theory (cf. Schepers \& Beach, 1998) (for an overview of such theories, see Frynas \& Croucher 2015; Rupp \& Mallory, 2015). Studies have applied psychological theories to demonstrate, inter alia, that CSR is positively related to employee social identification with their organization (e.g., Jones, 2010; Evans et al., 2011) or that CSR signals the values of an organization - and, hence, the potential for value congruence - to potential job applicants (e.g., Gully et al., 2013; Jones et al., 2014).

Recent reviews (Rupp \& Mallory, 2015; Glavas, 2016) showed that psychological perspectives on CSR are quickly gaining ground among scholars. Special issues of journals have been solely devoted to the intersection of CSR and organizational psychology (e.g., Andersson et al., 2013; Morgeson et al., 2013; Rupp et al., 2015). Perhaps unsurprisingly, psychology has arguably made the greatest contribution of recent years to nonmarket research. One recent review in a psychology journal went as far as to suggest that "With the rise of employee-focused microCSR research, person-centric work psychology, and humanitarian work psychology (HWP), a sea change is occurring regarding the field's perspective on CSR" (Rupp \& Mallory, 2015:212). This development informs the distinction between internally- and externally-directed CSR and their respective intentions. CSR directed toward employee well-being within the company may be primarily intended to raise productivity. CSR directed towards projects in the external society may be primarily intended to create political capital and, in this respect, be more closely allied to CPA.

A psychological perspective emphasizes that decisions on CSR and CPA activities are made and implemented either by individuals or teams of individuals. It draws attention to the significance of the "microfoundations" of such activities in terms of the individual actors 
responsible for them (Fellin, Foss \& Ployhart, 2015). The micro-foundations view of corporate CSR and CPA highlights the role and capabilities of those members of organizations who are the movers of these activities, together with the interactions they have both with each other and with external actors. It argues that these individual-level factors help to account for the ability of companies to formulate and sustain successful nonmarket policies and routines. In addition to the individuals' capabilities and relationships, a psychological perspective highlights the personal identities and espoused values of the actors involved in CSR and CPA, which are also expected to provide the motivation for their initiatives and to colour the meaning they attach to them. The interpretations that corporate actors and those in governmental and institutional agencies place on nonmarket strategies are likely to have a significant bearing on the acceptability and impact of those strategies.

Insights from psychology hold the key to understanding many aspects of nonmarket strategies at the individual level. Given that emerging scholarship has overwhelmingly focused on CSR activities, there is an enormous potential for exploring the psychological processes behind the political activities of companies. Psychological theories could help investigate, inter alia, the psychological drivers behind corporate political activities or CPA-CSR integration, and the mediating and moderating effects of CPA that are related, for example, to social and organizational identity or the perceived person-organization fit. We certainly expect that future nonmarket research will be increasingly conducted at the individual level of analysis and will provide a much richer understanding of the underlying psychological processes.

\section{Sociology and nonmarket research}

Sociology has already left an important mark on nonmarket research. Two of the main theories used in nonmarket research-institutional theory and resource-dependence theory-have their roots in sociology, while social movement theory and network theory have also left a mark (cf. Mellahi et al., 2016). Some of the psychological approaches in nonmarket research mentioned above — such as organizational justice theories (cf. Greenberg, 1987) - have roots in both psychology and sociology.

But sociology still has much to offer to the study of nonmarket strategies, and sociological contributions on nonmarket strategies have started to appear in leading sociology journals (Bartley, 2007; Lim \& Tsutsui, 2012; Walker \& Rea, 2014). Novel applications of sociological lenses - such as the institutional work lens within institutional theory (Gond, Cabantous \& Krikorian, 2017) or systems theory from the sociology of law (Sheehy, 2017)-illustrate the potential sociological contributions to nonmarket research yet to come. Curiously, we did not receive any submissions to this special issue specifically from a novel sociological perspective, if we exclude the more traditional institutional theory applications.

Research into CPA in particular could benefit from the application of another longstanding perspective within sociology-namely, a focus on organizational power and the conditions under which it is exercised. While some scholarship on CSR has explicitly acknowledged the critical importance of power relations (e.g., Banerjee, 2008; Bondy, 2008), in particular within global production chains (e.g., Levy, 2008; Tallontire, 2007), it would be appropriate for the analysis of CPA to take greater account of power and of the processes whereby power is generated and used. Following Pfeffer's (1981:7) aphorism that politics is 'power in action', a potentially fruitful approach to doing this is found in the political action analysis of corporate socio-political initiatives. This is premised on the view that power (or, more precisely, its exercise in the form of influence) does not necessarily follow mechanically from the possession 
of valuable resources but is also generated through persuasive actions that create legitimacy for corporate policies in the eyes of other actors. The political action perspective therefore regards the outcome of nonmarket strategies as depending on the process of how they are presented, interpreted, and negotiated within the relational framework (the network of social and political relations that companies have with external agencies) between corporate and external actors (Child, Tse \& Rodrigues, 2013). A fundamental assumption is that power operates through relationships such as these and 'is inseparable from interaction' (Clegg, Courpasson \& Phillips, 2006:6).

The political action approach within sociology draws attention to the power-related processes governing the implementation and evolution of CPA and CSR. Power is regarded as a capacity rather than as the exercise of that capacity (Lukes, 2005). In other words, a corporation's possession of a power resource gives it the potential to implement CSR and conduct effective CPA, but the outcome will depend on the dynamics of the relations with the other parties that are involved. This approach also allows for reaction and counter-action by institutional and other recipients of corporate nonmarket strategies. In so doing, it acknowledges the relevance of contrasting cultural and political contexts in informing that reaction. This indicates that a potentially fruitful way forward for research would be to address questions such as, for example, how power is located and exerted in different relational frameworks, or whether, in some contexts, CSR is a more effective nonmarket strategy than CPA and vice versa. We believe that the neglected study of power dynamics holds the key to understanding the boundaries of what is feasible in terms of implementing nonmarket strategies.

\section{Economics and nonmarket research}

Economics has already left an important mark on nonmarket research in the sense that many notable nonmarket strategy studies have applied economic analysis in conceptualizing and explicating problems in nonmarket research - for example, by investigating CSR with reference to the attributes of neo-classical equilibrium models or by conceptualizing nonmarket choices of companies as games with specific payoffs (e.g., notable contributions by Baron, 2001; King, 2007, and Kitzmueller \& Shimshack, 2012). Agency theory has become one of the most influential theoretical perspectives applied in nonmarket research (cf. Mellahi et al., 2016).

Transaction-cost economics has also left mark on nonmarket research, in particular investigating the transaction cost drivers that affect companies' governance choices with regard to CSR activities (e.g. Husted, 2003; King, 2007). Last but not least, game theory has contributed interesting insights to nonmarket research (e.g. Baron, 2001; Fairchild, 2008). Finally we should remember that institutional theory also has roots in the study of the regulatory role played by institutions in economics (Davis \& North, 1971; North, 1990) and this 'new institutional economics' lens has influenced nonmarket research (Bonardi, Holburn \& Vanden Bergh, 2006; De Figueiredo, 2009; Dorobantu, Kaul \& Zelner, 2017).

Leading literature reviews of nonmarket scholarship have, in recent years, emphasized the need for more scholarship on the micro-foundations of nonmarket strategies (Aguinis \& Glavas, 2012; Mellahi et al., 2016), and economics can arguably play an important role in the study of these micro-foundations. In fact, agency theory has been the leading lens for the understanding of micro-level phenomena in nonmarket research to-date. Micro-level studies conducted through the agency theory lens have, inter alia, investigated the link between CEO compensation and levels of CSR performance (e.g., Deckop et al., 2006, Berrone et al., 2010) and the link between the individual characteristics of top management team members and CSR- 
related decision making (e.g., Bear et al., 2010, Chin et al., 2013). However, agency theory has a relatively narrow focus on agent-principal relationships and hence provides only a partial explanation of nonmarket strategies.

The article by Boddewyn \& Buckley (2017) in this special issue inspired us to think that the micro-foundations of nonmarket strategies could be studied by looking at individual nonmarket transactions. Instead of studying the individual traits of decision-makers (using psychological theories or agency theory) or the relationships between an organization and its individual stakeholders (using stakeholder theory or resource-dependency theory), future researchers could apply the tools provided by transaction-cost economics to study individual transactions at the micro-level; for example, the individual transactions that occur between companies and NGOs or the individual transactions conducted by corporate charitable foundations. Such analysis could provide a wealth of insights on issues such as the nature of reciprocal exchanges, the capture of nonmarket actors by business, and the integration between social and political strategies.

Going beyond neo-classical economics, Austrian economics provides one alternative avenue for enriching individual-level perspectives on nonmarket strategy. In contrast to neo-classical economics and much of the extant nonmarket literature, Austrian economics regards human action - not external constraints - as fundamental to decision-making (e.g., Lachmann, 1956; Mises, 1963). While Austrian economists such as Mises (1963) viewed consumer demand as an external constraint, they suggested that the only acceptable research propositions are those relating to individual actions, and that all motivations of agents and institutions arise from individual behaviours (applying the Austrian concept of 'methodological individualism'). Austrian economics can provide a superior explanation for individual decisions, recognizing that, inter alia, value is subjective, manager-entrepreneurs can choose different courses of action, and information is interpreted differently by different actors (the Austrian concept of "asymmetric expectations"). The few studies that applied Austrian economics to CSR (Adams \& Whelan, 2009; Frynas, 2009; Maxfield, 2008) had no discernible influence on wider nonmarket scholarship, but nonmarket studies from an Austrian perspective could investigate, inter alia, asymmetric future expectations among individual managers with regard to nonmarket environments or the genesis of social and environmental innovations in companies as a result of entrepreneurial/intrapreneurial decision-making. Insights from Austrian economics have informed the micro-level perspective of the resource-based view in strategic management (Foss \& Ishikawa, 2007, Kraaijenbrink et al., 2010) and, conversely, there may be much value in applying Austrian economics to inform the micro-foundations of nonmarket behaviour.

\section{Political science and nonmarket research}

There is a long scholarly tradition pertaining to the investigation of the interactions between business interest groups and politics (Schattschneider, 1935; Gerschenkron, 1943) and, specifically, company-level corporate political activities (for an early review, see Shaffer, 1995; for a review of the recent CPA literature, see Lawton et al., 2013a). Political frameworks have influenced CPA and CSR research, as evidenced, inter alia, by the use of political economy ideas in the scholarship on business and politics, the application of the social contract concept in business ethics, and the reliance on Habermasian political theory in Political CSR research.

Influenced by pluralist theory scholarship in international relations (cf. McGuire, 2015), political economy ideas and concepts have found their way into business and politics research, 
helping to explain the increased structural power of companies in politics (e.g., Fuchs \& Ledererer, 2007; Farrell \& Newman, 2015). Influenced by the concept of the social contract in political theory (cf. Frynas \& Stephens, 2015), the social contract has been applied to issues of business ethics and CSR, particularly in the form of Donaldson \& Dunfee's Integrative Social Contracts Theory, as a way of explaining and legitimising the nonmarket (political and social) involvement of business without reliance on state regulation or indeed a legitimate state (e.g., Hartman et al., 2003; van Oosterhout et al., 2006). However, we must note that insights from political economy have largely failed to inform the CPA literature, just as social contract approaches have largely failed to inform the CSR literature, in the leading mainstream business journals.

In this context, the 'Political CSR' research stream has recently made a very important contribution by encouraging a wider discussion of corporate political engagement in business schools and in mainstream business journals. Inspired by and selectively borrowed from the political writings of Jürgen Habermas (cf. Whelan 2012), Scherer \& Palazzo (2007, 2011) offered a normative Political CSR conception, portraying a vision of a global society in which non-state actors legitimately provide public goods to satisfy human development needs. They adopted the Habermasian political concept of 'deliberative democracy' as a way of addressing the legitimacy gap created by the involvement of non-state actors in political decision-making. Scherer \& Palazzo's conception has attracted considerable follow-up work (e.g., Levy et al., 2016; Lock \& Seele, 2016; Scherer et al., 2016).

However, there was a notable absence of political scientists in Political CSR debates, Habermasian ideas were incompletely adapted and normative Political CSR scholarship failed to offer any predictive power (see critique by Whelan, 2012). The lack of involvement of political scientists manifested itself, for example, in the axiomatic misconception of this literature with regard to the decline of state power as a key explanation of nonmarket strategies, despite evidence from political science that state power vis-à-vis companies remains strong and is a prerequisite for successful economic globalization (e.g., Evans, 1997; Weiss, 2000; Kim, 2013; Micklethwait \& Wooldridge, 2014).

We are left with the impression that political theory has still failed to fulfil its full promise with regard to informing nonmarket scholarship. Going beyond their function in business ethics research, social contract theories could be applied to study, for instance, how the strength of the social contract between the state and its citizens across a multinational company's different host countries serves to either legitimize or delegitimize nonmarket strategies and affects the success and failure of such strategies. Going beyond normative Political CSR research, Habermasian ideas could help to understand, inter alia, how different discourses around nonmarket issues may be manipulated by the media, the companies, and governments with different vested interests, yielding deeper insights that are currently unavailable through applied linguistic analysis. In more general terms, insights from political theory and international relations can help to explain political changes at the domestic and global levels that affect the nonmarket arena, inter alia, much beyond the currently popular institutional theory that is unable to effectively explain the structural causes of global institutional changes (cf. Wood et al., 2014).

History and nonmarket research 
Business history directly informed the birth of some business disciplines in the $20^{\text {th }}$ century in that detailed historical evidence informed, inter alia, John Dunning's OLI paradigm in international business (Jones and Khanna, 2006) and Alfred D. Chandler's ideas in strategic management (Witzel, 2012:164-165). However, as the influence of business history has gradually waned in business and management generally, its contribution to the development of nonmarket strategy scholarship has also been negligible.

We believe that historical evidence could significantly enrich our understanding of nonmarket strategies, not least since the development of nonmarket resources by companies has been shown to be linked to long-term cooperative interactions and reciprocity by the actors involved (Frynas et al., 2006; Sun et al., 2010). In line with those historians who have pointed to the benefits of robust longitudinal historical case studies in business research (Jones \& Khanna, 2006; Carr \& Lorenz, 2014), we think that nonmarket strategy research could fruitfully utilise such studies to investigate how companies acquire, integrate, and sustain political and social resources and how nonmarket strategies evolve in the long term.

As Morck \& Yeung (2007:358-359) suggested, historical evidence has the great merit of uncovering the direction of causality, given that "any causal explanation must be consistent with both time series and cross-sectional variation". Robust historical case studies can be instrumental in understanding causality, especially if abundant case studies are available across a panel of data. By extension, historical research could help to address, inter alia, one of the most studied and still ambiguous concerns in nonmarket strategies: the nature of the nonmarket strategy-performance link (cf. Mellahi et al., 2016). Historical case studies of a large number of companies could help us to confidently answer the question obscured by statistical data: whether nonmarket strategies lead to positive organizational performance or - as suggested by some writers - that it is actually above-average organizational performance that enables managers to spend corporate funds on nonmarket initiatives, often as personal perquisites.

The very few available journal articles on corporate political activities and corporate social responsibility that painstakingly utilize evidence from historical archives (Frynas et al., 2006; Decker, 2011; Harvey, 2016) point to the potential of historical sources for advancing nonmarket research. Frynas et al.'s (2006) historical evidence on the political activities of British oil companies under colonialism demonstrates how archival sources (e.g., confidential letters and memos) can tell us what motivated government officials to support some business interests, which can provide a more honest picture of personal motivations that would be scarcely possible through the use of interviews. Harvey's (2016) historical case study of coal mining safety in $19^{\text {th }}$ century Britain demonstrates the closeness of social responsibility concerns and the political ties of companies, which can provide a comparative reference to today's ahistorical debates on Political CSR. History has surely much to offer to nonmarket scholars.

\section{Contributions in this special issue}

The first paper in our special issue by Boddewyn \& Buckley (2017) provides a new take on transaction-cost economics in conjunction with relational-model theory, which helps to provide an explanation of how goods can be obtained from others without using transactions - namely through non-contractual reciprocity. The authors demonstrate how the concept of reciprocity can provide a fruitful way for integrating social and political strategies given that CSR 
strategies such as philanthropy and CPA strategies such as lobbying share the feature of donating valuable resources to nonmarket recipients. The contribution by Boddewyn \& Buckley (2017) is particularly valuable, as it allows for future researchers to investigate the interactions between social and political aspects of nonmarket strategy with a novel approach at the micro-level.

The next paper by Shirodkar, Konara \& McGuire (2017) utilizes the institutional theory in tandem with the organisational imprinting lens to contend that MNEs founded in countries with stronger regulatory institutions are likely to spend more on lobbying in a host country as compared to MNEs founded in countries with weaker regulatory institutions. While institutional theory cannot explain why MNEs act on the basis of some institutional influences but not others, the imprinting theory provides a missing explanation for why home country institutional influences may imprint themselves on organizations. In general terms, this paper demonstrates how nonmarket strategy research can benefit from applying theories with origins in the natural sciences (imprinting theory originated in biology) with regards to providing a better understanding of the evolution of nonmarket strategies.

The third paper by Liedong, Mellahi \& Rajwani (2017) integrates social capital and institutional theories to investigate the efficacy of managerial political ties (MPTs) and corporate social responsibility (CSR) in institutional risk reduction. Using survey data from 179 firms in Ghana, the authors find that whereas CSR reduces institutional risk exposure, MPTs do not. Furthermore, Liedong, Mellahi \& Rajwani show that the effect of MPTs on risk exposure is moderated by public affairs functions, but contrary to the extant literature, there is no corroborative evidence of complementarity between MPT and CSR - contrary to the assumptions of previous scholars such as den Hond et al. (2014) and Rehbein \& Schuler (2015).

Drawing on the resource dependence theory and the resource-based view, the fourth paper by Ahammad, Tarba, Frynas, and Scola (2017) investigates the interactions between market and nonmarket activities of firms in the context of the post-merger integration phase in cross-border mergers and acquisitions (M\&As). Based on a cross-country survey of $111 \mathrm{M} \& \mathrm{~A}$ practitioners, the authors went beyond current research on nonmarket strategy in M\&As by considering both political and social aspects of nonmarket strategy in their research design. The authors concluded, among others, that adaptability in the nonmarket environment is positively correlated with adaptability in the market environment, and in turn adaptability in the market environment leads to positive organizational performance of a cross-border M\&A, thus providing further support for the value of the alignment between market and nonmarket activities and filling a gap in the extant literature on the market-nonmarket interactions in postmerger integration.

In different ways, these four papers fulfil the aims of this special issue and help to provide novel insights for nonmarket research. The Boddewyn \& Buckley (2017) demonstrates how a theory from economics (i.e. transaction-cost economics), which has already been used in nonmarket research for a long time, can provide very novel insights. While the paper by Shirodkar, Konara \& McGuire (2017) demonstrates how a theoretical lens with origins in biology (i.e. imprinting theory) that has rarely been mentioned in nonmarket research can yield 
key missing insights, too. In more general terms, we think that both economics and biology may still have much to offer nonmarket researchers - we can think of Austrian economics or the theory of autopoiesis, for example. But ultimately, we think that nonmarket researchers would greatly benefit from actually collaborating in joint research projects with non-business specialists, who will inevitably have a superior understanding of non-business theories and methodologies. We believe that we need to keep breaking down disciplinary boundaries, since genuine inter-disciplinary cross-fertilization can be potentially invaluable.

The papers by Liedong, Mellahi \& Rajwani (2017) and Ahammad, Tarba, Frynas, and Scola (2017) provide some novel insights on the integration of social and political strategies, and the integration of market and nonmarket strategies. But they have practical implications too. They suggest, for example, that complementarity effects between CSR and CPA cannot be taken for granted and the efficacy of such complementarity may fundamentally differ between different developing/emerging markets, and that managers may want to consider to what extent certain nonmarket strategies are appropriate in mergers and acquisitions at different points in time because the critical resources required for M\&A success may greatly differ between different phases of the M\&A process. We surely need more insights of this nature to move the nonmarket research forward. We simply hope that, in its modest way, our special issue will stimulate more research that will utilize novel approaches and provide more integrative perspectives.

\section{Acknowledgements}

The authors are very grateful to Prof. Kamel Mellahi whose constructive comments have helped us to improve this paper. 


\section{References}

Adams, C.A. \& G. Whelan (2009). 'Conceptualising future change in corporate sustainability reporting', Accounting, Auditing \& Accountability Journal, 22, pp. 118-143.

Aguinis, H. \& A. Glavas (2012). 'What We Know and Don't Know About Corporate Social Responsibility: A Review and Research Agenda', Journal of Management, 38, pp. 932-968.

Ahammad, M., S. Tarba, J. G. Frynas \& A. Scola (2017). 'Integration of nonmarket and market activities in cross-border mergers and acquisitions', British Journal of Management, 52, pp.

Alakent, E. \& M. Ozer (2014). 'Can companies buy legitimacy? Using corporate political strategies to offset negative corporate social responsibility records'. Journal of Strategy and Management, 7, pp. 318 - 336 .

Andersson, L., S.E. Jackson \& S.V. Russell (2013). 'Greening organizational behavior: An introduction to the special issue'. Journal of Organizational Behavior, 34, pp. 151-155.

Arya, B., \& Zhang, G. (2009). 'Institutional reforms and investor reactions to CSR announcements: Evidence from an emerging economy'. Journal of Management Studies, 46, pp. 1089-1112.

Astley, W.G. (1985). 'Administrative science as socially constructed truth'. Administrative Science Quarterly, 30, pp. 497-513.

Abolafia, M.Y. (1998). 'Markets as cultures: An ethnographic approach'. Sociological Review, 46(S1), pp. 69-85.

Banerjee, B. (2008). 'Corporate Social Responsibility: The Good, the Bad and the Ugly'. Critical Sociology, 34, pp. 51-79.

Baron, D.P. (1995). 'Integrated strategy: Market and nonmarket components'. California Management Review, 37, pp. 47-65.

Baron, D.P. (2001). 'Private Politics, Corporate Social Responsibility and Integrated Strategy', Journal of Economics and Management Strategy, 10, pp. 7-45.

Barron, A., A. Pereda \& S. Stacey (2017). 'Exploring the performance of government affairs subsidiaries: A study of organisation design and the social capital of European government affairs managers at Toyota Motor Europe and Hyundai Motor Company in Brussels'. Journal of World Business, 52, pp. 184-196.

Bartley, T. (2007). 'Institutional emergence in an era of globalization: The rise of transnational private regulation of labor and environmental conditions'. American Journal of Sociology, 113, pp. 297-351.

Bear, S., N. Rahman, \& C. Post (2010). 'The Impact of Board Diversity and Gender Composition on Corporate Social Responsibility and Firm Reputation', Journal of Business Ethics, 97, pp. 207-221.

Berrone, P., C. Cruz, L. Gomez-Mejia \& M. Larraza-Kintana (2010). 'Socioemotional Wealth and Corporate Responses to Institutional Pressures: Do Family-Controlled Firms Pollute Less?'. Administrative Science Quarterly, 55, pp. 82-113.

Bondy, K. (2008). 'The Paradox of Power in CSR: A Case Study on Implementation', Journal of Business Ethics, 82, pp. 307-323. 
Boddewyn, J. (2016). 'International business-government relations research 1945-2015: Concepts, typologies, theories and methodologies'. Journal of World Business, 51, pp. 10 22.

Boddewyn, J. \& T.L. Brewer (1994). 'International business political behavior: New theoretical directions'. Academy of Management Review, 19, pp. 119-143.

Boddewyn, J. \& P. Buckley (2017). 'Integrating Social and Political Strategies as Forms of Reciprocal Exchange into the Analysis of Corporate Governance Modes', British Journal of Management, 52, pp.

Bonardi, J.P., G.L.F. Holbum \& R.G. Vanden Bergh (2006). 'Nonmarket strategy performance: Evidence from U.S. electric utilities', Academy of Management Journal, 38, pp. 288-303.

Busch, T., R. Bauer \& M. Orlitzky (2016). 'Sustainable development and financial markets: Old paths and new avenues’. Business \& Society, 55, pp. 303 -329.

Carr, C. \& A. Lorenz (2014). 'Robust strategies: Lessons from GKN 1759-2013'. Business History, 56, pp. 1169-1195.

Child, J., K.K-T. Tse \& S.B. Rodrigues (2013). The Dynamics of Corporate Co-evolution. Cheltenham: Edward Elgar.

Chin, M. K., D. C. Hambrick, \& L.K. Treviño (2013). 'Political ideologies of CEOs: The influence of executives' values on corporate social responsibility', Administrative Science Quarterly, 58, pp. 197-232.

Clegg, S.R., D. Courpasson \& N. Phillips (2006). Power and Organizations. Thousand Oaks, CA: Sage.

Crampton, W. \& D. Patten (2008). 'Social responsiveness, profitability and catastrophic events: Evidence on the corporate philanthropic response to 9/11', Journal of Business Ethics, 81, pp. 863-873.

Darendeli, I. S. \& T. L. Hill (2016). 'Uncovering the Complex Relationships between Political Risk and MNE Firm Legitimacy: Insights from Libya', Journal of International Business Studies, 47, pp. 68-92.

Davis, L.E. \& D.C. North (1971). Institutional Change and American Economic Growth. Cambridge: Cambridge University Press.

Decker, S. (2011). 'Corporate political activity in less developed countries: The Volta River Project in Ghana, 1958-66'. Business History, 53, pp. 993-1017.

Deckop, J. R., K.K. Merriman \& S. Gupta (2006). 'The Effects of CEO Pay Structure on Corporate Social Performance'. Journal of Management, 32, pp. 329-342.

De Figueiredo, J.M. (2009). 'Integrated political strategy', Advances in Strategic Management, 26, pp. 459-486.

den Hond, F., K.A. Rehbein, F.G.A. de Bakker \& H. K. Lankveld HK. (2014). 'Playing on two chessboards: Reputation effects between corporate social responsibility (CSR) and corporate political activity (CPA)'. Journal of Management Studies, 51, pp. 790-813.

Dieleman, M. \& J.J. Boddewyn (2012). 'Using organization structure to buffer political ties in emerging markets: A case study’. Organization Studies, 33, pp. 71-95. 
Doh, J., T. Lawton, T. Rajwani \& S. Paroutis (2014). 'Why your company may need a chief external officer: Upgrading external affairs can help align strategy and improve competitive advantage'. Organization Dynamics, 43, pp. 96-104.

Dorobantu, S., A. Kaul \& B. Zelner (2017). 'Nonmarket strategy research through the lens of new institutional economics: An integrative review and future directions'. Strategic Management Journal, 38, pp. 114-140.

Elkington, J. (1994). 'Towards the Sustainable Corporation: Win-Win-Win Business Strategies for Sustainable Development'. California Management Review, 36, pp. 90-100.

Evans, P. (1997). 'The Eclipse of the State? Reflections on Stateness in an Era of Globalization'. World Politics, 50, pp. 62-87.

Evans, W. R., W. D. Davis, \& D. D. Frink (2011). 'An examination of employee reactions to perceived corporate citizenship', Journal of Applied Social Psychology, 41, pp. 938-964.

Fairchild, R. (2008). 'The Manufacturing Sector's Environmental Motives: A Game-theoretic Analysis'. Journal of Business Ethics, 79, pp. 333-344.

Farrell, H. \& A.L. Newman (2015). 'Structuring power: Business and authority beyond the nation state'. Business and Politics, 17, pp. 527-552.

Fellin, T., N.J. Foss \& R.E. Ployhart (2015). 'The Microfoundations Movement in Strategy and Organization Theory'. Academy of Management Annals, 9, pp.575-632.

Fligstein, N. (1996). 'A Political-Cultural Approach to Market Institutions', American Sociological Review, 61, pp. 656-673.

Foss, N. J. \& I. Ishikawa (2007). 'Towards a dynamic resource-based view: Insights from Austrian capital and entrepreneurship theory', Organization Studies, 28, pp. 749-772.

Frynas, J.G. (2009). Beyond Corporate Social Responsibility - Oil Multinationals and Social Challenges. Cambridge: Cambridge University Press.

Frynas, J.G. (2015). 'Strategic CSR, value creation and competitive advantage. In Lawton, T. C. \& Rajwani, T. S. (Eds.), The Routledge Companion to Non-Market Strategy: 245-262. Abingdon: Routledge.

Frynas, J.G. \& R. Croucher (2015). 'Editorial: Employee Responses to Changing Work Practices', British Journal of Management, Virtual Issue: Employee Responses to Changing Work Practices, DOI: 10.1111/1467-8551.12112.

Frynas, J.G., K. Mellahi \& G. Pigman (2006). 'First mover advantages in international business and firm-specific political resources'. Strategic Management Journal, 27, pp. 321345 .

Frynas J.G. \& S. Stephens (2015). 'Political corporate social responsibility: Reviewing theories and setting new agendas'. International Journal of Management Reviews, 17, pp. 483-509.

Fuchs, D. \& M. Ledererer (2007). 'The power of business'. Business and Politics, 9(3), pp.117.

Gao, Y. \& T. Hafsi (2017). 'Political dependence, social scrutiny, and corporate philanthropy: Evidence from disaster relief', Business Ethics: A European Review, 26, pp.189-203. 
Gerschenkron, A. (1943). Bread and democracy in Germany. Berkeley: University of California Press.

Glavas, A. (2016). 'Corporate Social Responsibility and Organizational Psychology: An Integrative Review’. Frontiers in Psychology, DOI: 10.3389/fpsyg.2016.00144.

Gond, J.P., L. Cabantous \& F. Krikorian (2017). 'How do things become strategic?: "Strategifying” corporate social responsibility'. Strategic Organization, DOI: $10.1177 / 1476127017702819$.

Grant, A. M., J. E. Dutton \& B. D. Rosso (2008). 'Giving commitment: Employee support programs and the prosocial sensemaking process', Academy of Management Journal, 51, pp. 898-918.

Greenberg, J. (1987). 'A Taxonomy of Organizational Justice Theories', Academy of Management Review, 12, pp. 9-22.

Gully, S.M., J.M. Phillips, W.G. Castellano, K. Han \& A. Kim (2013). 'A mediated moderation model of recruiting socially and environmentally responsible job applicants'. Personnel Psychology, 66, pp. 935-973.

Hart, S.L. (1995). 'A Natural Resource-Based View of the Firm', Academy of Management Review, 20, pp. 986-1014.

Hartman, L.P., B. Shaw \& R. Stevenson (2003). 'Exploring the Ethics and Economics of Global Labor Standards: A Challenge to Integrated Social Contract Theory'. Business Ethics Quarterly, 13, pp. 193-220.

Harvey, B. (2016). 'The Oaks Colliery disaster of 1866: A case study in responsibility', Business History, 58, pp. 501-531.

Helmig, B., K. Spraul \& D. Ingenhoff (2016). 'Under positive pressure: How stakeholder pressure affects corporate social responsibility implementation'. Business \& Society, 55, pp. 151-187.

Hillenbrand, C., K. Money \& A. Ghobadian (2013). 'Unpacking the Mechanism by which Corporate Responsibility Impacts Stakeholder Relationships'. British Journal of Management, 24, pp. 127-146.

Hillman, A.J., G.D. Keim \& D. Schuler (2004). 'Corporate political activity: A review and research agenda'. Journal of Management, 30, pp. 837-857.

Holburn, G.L.F., \& R.G. Vanden Bergh (2014). 'Integrated market and nonmarket strategies: Political campaign contributions around merger and acquisition events in the energy sector'. Strategic Management Journal, 35, pp. 450-460.

Husted, B.W. (2003). 'Governance Choices for Corporate Social Responsibility: to Contribute, Collaborate or Internalize?', Long Range Planning, 36, pp. 481-498.

Jamali, D. \& R. Mirshak (2010). 'Business-conflict linkages: Revisiting MNCs, CSR, and conflict', Journal of Business Ethics, 93, pp. 443-464.

Jia, N. (2014). 'Are collective political actions and private political actions substitutes or complements? Empirical evidence from China's private sector', Strategic Management Journal, 35, pp. 292-315.

Jones, G. \& T. Khanna (2006). 'Bringing history (back) into international business'. Journal of International Business Studies, 37, pp. 453-468. 
Jones, D.A. (2010). Does serving the community also serve the company? Using organizational identification and social exchange theories to understand employee responses to a volunteerism programme. Journal of Occupational and Organizational Psychology, 83, 857-878.

Jones, D.A., C.A. Willness \& A. Madey (2014). 'Why are job seekers attracted by corporate social performance? Experimental and field tests of three signal-based mechanisms'. Academy of Management Journal, 57, pp. 383-404.

Kim, S.Y. (2013). 'The Rise of East Asia's Global Companies', Global Policy, 4, pp. 184193.

Kim, E.H. \& T.P. Lyon (2011). 'Strategic environmental disclosure: Evidence from the DOE's voluntary green-house gas registry', Journal of Environmental Economics and Management, 61, pp. 311-326.

King, A.A. (2007). 'Cooperation between Corporations and Environmental Groups: A Transaction Cost Perspective', Academy of Management Review, 32, pp. 889-900.

Kitzmueller, M. \& J. Shimshack (2012). 'Economic Perspectives on Corporate Social Responsibility', Journal of Economic Literature, 50, pp. 51-84.

Kobrin, S.J. (2015). 'Is a global nonmarket strategy possible? Economic integration in a multipolar world order'. Journal of World Business, 50, pp. 262-272.

Kolk, A. and J. Pinkse (2007). 'Multinationals' political activities on climate change'. Business and Society, 46, pp. 201-228.

Kraaijenbrink, J., J.C. Spender \& A.J. Groen (2010). 'The Resource-Based View: A Review and Assessment of Its Critiques', Journal of Management, 36, pp. 349-372.

Lachmann, L.M. (1956). Capital and its structure. Kansas City: Sheed Andrews and McNeel.

Lawton, T., S. McGuire \& T. Rajwani (2013a). 'Corporate Political Activity: A Literature Review and Research Agenda', International Journal of Management Reviews, 15, pp. 86105.

Lawton, T., T. Rajwani \& J. Doh (2013b). 'The antecedents of political capabilities: A study of ownership, cross-border activity and organization at legacy airlines in a deregulatory context'. International Business Review, 22, pp. 228-242.

Levy, D.L. (2008). 'Political Contestation in Global Production Networks', Academy of Management Review, 33, pp. 943-963.

Levy, D.L. \& D. Egan (2003). 'A Neo-Gramscian Approach to Corporate Political Strategy: Conflict and Accommodation in the Climate Change Negotiations', Journal of Management Studies, 40, pp. 803-829.

Levy, D. L., J. Reinecke and S. Manning (2016). 'The political dynamics of sustainable coffee: Contested value regimes and the transformation of sustainability', Journal of Management Studies, 53, pp. 364-401.

Liedong, T.A., A. Ghobadian, T. Rajwani \& N. O'Regan (2015). 'Toward a View of Complementarity: Trust and Policy Influence Effects of Corporate Social Responsibility and Corporate Political Activity', Group \& Organization Management, 40, pp. 405-427. 
Liedong, T.A., K. Mellahi \& T. Rajwani (2017). 'Reality or Illusion? The Efficacy of Nonmarket Strategy in Institutional Risk Reduction', British Journal of Management, 52, pp.

Lim, A. \& K. Tsutsui (2012). 'Globalization and commitment in corporate social responsibility: Cross-national analyses of institutional and political-economy effects'. American Sociological Review, 77, pp. 69-98.

Lin, K.J., J. Tan, L. Zhao \& K. Karim (2015). 'In the name of charity: Political connections and strategic corporate social responsibility in a transition economy'. Journal of Corporate Finance, 32, pp. 327-346.

Lock, I. \& P. Seele (2016). 'Deliberative lobbying? Toward a noncontradiction of Corporate Political Activities and Corporate Social Responsibility?'. Journal of Management Inquiry, 25, pp. 415-430.

Lord, R.G. \& K.J. Maher (1991). 'Cognitive theory in industrial and organizational psychology'. In M. Dunnette and L. Hough (eds.), Handbook of industrial organizational psychology, 2, pp. 1-62. Palo Alto, CA: Consulting Psychologist Press.

Lukes S. (2005). Power: A Radical View. Basingstoke Palgrave Macmillan, $2^{\text {nd }}$ edition.

Maxfield, S. (2008). 'Reconciling Corporate Citizenship and Competitive Strategy: Insights from Economic Theory', Journal of Business Ethics, 80, pp. 367-377.

McDonnell, M.H. \& T. Werner (2016). 'Blacklisted Businesses: Social Activists' Challenges and the Disruption of Corporate Political Activity', Administrative Science Quarterly, 61, pp. 584-620.

McGuire, S. (2015). 'The uneasy interplay between non-market strategy and international relations'. In: T. C. Lawton and T. Rajwani (eds.) The Routledge Companion to Nonmarket Strategy, Abingdon: Routledge.

McWilliams, A., D.D. van Fleet \& K.D. Cory (2002). 'Raising rivals' costs through political strategy: an extension of resource-based theory', Journal of Management Studies, 39, pp. $707-723$.

McWilliams, A. \& D.S. Siegel (2011). 'Creating and Capturing Value: Strategic Corporate Social Responsibility, Resource-Based Theory, and Sustainable Competitive Advantage', Journal of Management, 37, pp. 1480-1495.

Mellahi, K., J.G. Frynas, P. Sun \& D. Siegel, (2016). 'A Review of the Nonmarket Strategy Literature: Towards a Multi-Theoretical Integration'. Journal of Management, 42, pp. 143173.

Micklethwait, J. \& A. Wooldridge (2014). The Fourth Revolution: The Global Race to Reinvent the State. London: Allen Lane.

Mises, L. (1963). Human Action, 3rd edition. Chicago, IL: Yale University Press.

Morck, R. \& B. Yeung (2007). 'History in perspective: comment on Jones and Khanna "Bringing history (back) into international business"'. Journal of International Business Studies, 38, pp. 357-360.

Morgeson, F.P., H. Aguinis, D.A. Waldman \& D.S. Siegel (2013). 'Extending Corporate Social Responsibility Research to the Human Resource Management and Organizational Behavior Domains: A Look to the Future'. Personnel Psychology, 66, pp. 805-824. 
Nalick, M., M. Josefy, A. Zardkoohi \& L. Bierman (2016). 'Corporate sociopolitical involvement: A reflection of whose preferences?', Academy of Management Perspectives, 30, pp. 384-403.

North, D.C. 1990. Institutions, Institutional Change and Economic Performance. Cambridge: Cambridge University Press.

Oliver, C., \& I. Holzinger, (2008). 'The effectiveness of strategic political management: A dynamic capabilities framework', Academy of Management Review, 33, pp. 496-520.

Orlitzky, M. (2011). 'Institutional logics in the study of organizations: The social construction of the relationship between corporate social and financial performance', Business Ethics Quarterly, 21, pp. 409-444.

Örtenblad, A. (2016). Research Handbook on Corporate Social Responsibility in Context. Cheltenham: Edward Elgar.

Pfeffer, J. 1981. Power in Organizations. Marshfield, MA: Pitman.

PricewaterhouseCoopers (2016). 'Redefining business success in a changing world - CEO Survey'. London: PricewaterhouseCoopers.

Rajwani, T. \& T.A. Liedong (2015). 'Political activity and firm performance within nonmarket research: A review and international comparative assessment'. Journal of World Business, 50, pp. 273-283.

Rehbein, K., \& D.A. Schuler (2015). 'Linking corporate community programs and political strategies: A resource-based view’. Business \& Society, 54: 794-821.

Robinson, S.L, M.S. Kraatz \& D.M. Rousseau (1994). 'Changing obligations and the psychological contract: A longitudinal study', Academy of Management Journal, 37, pp. 137152.

Rodriguez, P., D.S. Siegel, A. Hillman \& L. Eden (2006). 'Three lenses on the multinational enterprise: Politics, corruption, and corporate social responsibility'. Journal of International Business Studies, 37, pp. 733-746.

Rupp, D.E. and D.B. Mallory (2015). 'Corporate Social Responsibility: Psychological, PersonCentric, and Progressing'. Annual Review of Organizational Psychology and Organizational Behavior, 2, pp. 211-36.

Rupp, D.E., P.M. Wright, S. Aryee \& Y. Luo (2015). 'Organizational Justice, Behavioral Ethics, and Corporate Social Responsibility: Finally the Three Shall Merge'. Management and Organization Review, 11, 185-186.

Russo, M.V. \& P.A. Fouts (1997). 'A resource-based perspective on corporate environmental performance and profitability’. Academy of Management Journal, 40, pp. 534-559.

Schattschneider, E.E. (1935). Politics, pressures and the tariff. A study of free enterprise in pressure politics as shown in the 1929-1930 revision of the tariff. New York: Prentice Hall.

Schepers, D.H. \& L.R. Beach (1998). 'An Image Theory View of Worker Motivation'. In L. R. Beach (ed.), Image theory: Theoretical and empirical foundations, pp. 125-132. Mahwah, NJ: Lawrence Erlbaum Associates.

Scherer, A.G. \& G. Palazzo (2007). 'Toward a political conception of corporate responsibility: Business and society seen from a Habermasian perspective'. Academy of Management Review, 32, pp. 1096-1120. 
Scherer, A.G. \& G. Palazzo (2011). 'The new political role of business in a globalized world: A review of a new perspective on CSR and its implications for the firm, governance and democracy'. Journal of Management Studies, 48, pp. 899-931.

Scherer, A.G., A. Rasche, G. Palazzo \& A. Spicer (2016). 'Managing for Political Corporate Social Responsibility: New challenges and directions for PCSR 2.0'. Journal of Management Studies, 53, pp. 273-298.

Shaffer, B. (1995). 'Firm-level responses to government regulation: Theoretical and research approaches'. Journal of Management, 21, pp. 495-514.

Sheehy, B. (2017). 'Private and public corporate regulatory systems: Does CSR provide a systemic alternative to public law?'. UC Davis Business Law Journal, 17, pp. 1-56.

Shirodkar, V., Konara \& S. McGuire (2017). 'Home Institutional Imprinting, R\&D Intensity and Lobbying Expenditure of Foreign Firms in the U.S', British Journal of Management, 52.

Siegel, J. (2007). 'Contingent political capital and international alliances: Evidence from South Korea', Administrative Science Quarterly, 52, pp. 621-666.

Suddaby, R., C. Hardy \& Q.N. Huy (2011). 'Where are the new theories of organization?'. Academy of Management Review, 36, pp. 236-246.

Sun, P., K. Mellahi \& E. Thun (2010). 'The dynamic value of MNE political embeddedness: The case of the Chinese automobile industry', Journal of International Business Studies, 41, pp. 1161-1182.

Sun P, K. Mellahi \& M. Wright (2012). 'The contingent value of corporate political ties', Academy of Management Perspectives, 26, pp. 68-82.

Tallontire, A. (2007). 'Who Regulates the Agri-food Chain? Towards a framework for understanding private standards initiatives', Third World Quarterly, 28, pp. 775-791.

van Oosterhout, P., J. Heugens \& M. Kaptein (2006). 'Foundations and applications for contractualist business ethics', Journal of Business Ethics, 68, pp. 211-228.

Walker, E.T. (2012). 'Putting a Face on the Issue: Corporate Stakeholder Mobilization in Professional Grassroots Lobbying Campaigns', Business \& Society, 51, pp. 561-601.

Walker, E.T. \& Rea, C.M. (2014). 'The political mobilization of firms and industries', Annual Review of Sociology, 40, pp. 281-304.

Wang, H. \& C. Qian (2011). 'Corporate philanthropy and corporate financial performance: The roles of stakeholder response and political access', Academy of Management Journal, 54, pp. $1159-1181$.

Werner, T. (2017). 'Investor reaction to covert corporate political activity'. Strategic Management Journal. DOI: 10.1002/smj.2682.

Whelan, G. (2012). 'The political perspective of corporate social responsibility: a critical research agenda', Business Ethics Quarterly, 22, pp. 709-737.

Whetten, D.A., T. Felin \& B.G. King (2009). 'The practice of theory borrowing in organizational studies: Current issues and future directions', Journal of Management, 35, pp. 537-563.

Witzel, M. (2012). A History of Management Thought. London: Routledge. 
Weiss, L. (2000). 'Globalization and State Power', Development and Society, 29, pp. 1-15.

Wood, G., P. Dibben \& S. Ogden (2014). 'Comparative Capitalism without Capitalism, and Production without Workers: The Limits and Possibilities of Contemporary Institutional Analysis', International Journal of Management Reviews, 16, pp. 384-396.

World Economic Forum (2016). 'The Global Risks Report 2016 - 11 $1^{\text {th }}$ edition'. Geneva: World Economic Forum.

Zhang, J., C. Marquis \& K. Qiao (2016). 'Do Political Connections Buffer Firms from or Bind Firms to the Government? A Study of Corporate Charitable Donations of Chinese Firms', Organization Science, 27, pp. 1307-1324. 
Table 1. Additional Theoretical Perspectives in Future Nonmarket Strategy Research

\section{Theoretical Perspectives Key Research Questions}

\begin{tabular}{|c|c|}
\hline Psychological theories & $\begin{array}{l}\text { How do personal identities and values of the individual } \\
\text { actors involved in nonmarket strategy influence CSR } \\
\text { and CPA and interactions between them? What effect } \\
\text { do they have on the acceptability and impact of those } \\
\text { strategies? }\end{array}$ \\
\hline Organizational power & $\begin{array}{l}\text { How is power located and exerted in different } \\
\text { relational frameworks? What are the power-related } \\
\text { processes governing the implementation and evolution } \\
\text { of nonmarket strategies? }\end{array}$ \\
\hline Transaction-cost economics & $\begin{array}{l}\text { How does non-contractual reciprocity affect nonmarket } \\
\text { strategies? How do individual transactions between } \\
\text { companies and nonmarket actors reveal the nature of } \\
\text { reciprocal exchanges, the capture of nonmarket actors } \\
\text { by business, or the integration between CSR and CPA? }\end{array}$ \\
\hline Austrian economics & $\begin{array}{l}\text { How do asymmetric future expectations among } \\
\text { individual managers affect nonmarket strategies or the } \\
\text { development of social and environmental innovations? }\end{array}$ \\
\hline Social contract & $\begin{array}{l}\text { How do the nature and strength of the social contract } \\
\text { between citizens and the state influence differences } \\
\text { between nonmarket conduct and subsequently } \\
\text { organizational performance across different national } \\
\text { contexts? }\end{array}$ \\
\hline Habermasian theories & $\begin{array}{l}\text { How do discourses and societal power structures reveal } \\
\text { different normative assumptions and forms of } \\
\text { communication behind notions of organizational } \\
\text { performance in different institutional contexts? }\end{array}$ \\
\hline Biological theories & $\begin{array}{l}\text { How can we draw parallels between organizational } \\
\text { behaviour and biological processes to better } \\
\text { understand the implementation and evolution of } \\
\text { nonmarket strategies? }\end{array}$ \\
\hline
\end{tabular}


Figure 1: The possible interactions between CSR and CPA

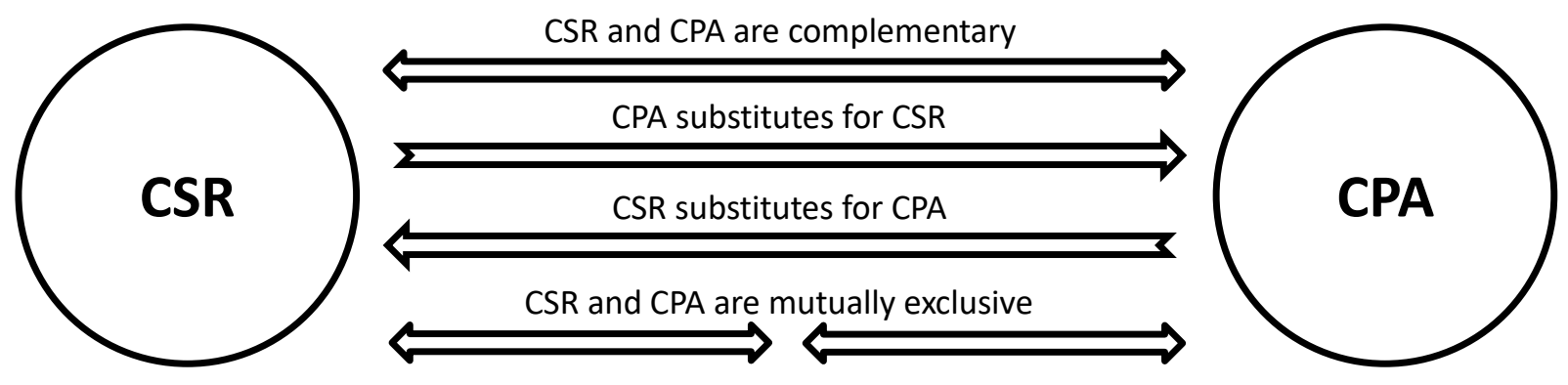

